\title{
Population status and distribution of Assamese macaques (Macaca assamensis) in Kaligandaki river basin of Baglung and Parbat districts, Nepal
}

\author{
Pavan Kumar Paudel ${ }^{1} \bowtie$ and Mukesh Kumar Chalise ${ }^{1}$ \\ ${ }^{1}$ Central Department of Zoology, Tribhuvan University, Kirtipur, Kathmandu, Nepal \\ pavanreturn@gmail.com
}

\begin{abstract}
Population status and distribution of Assamese monkey in Kaligandaki river basin was studied by direct count method and block design. Field research was conducted from November, 2015 to June, 2016. The total area of $104.70 \mathrm{~km}^{2}$ was surveyedto determine the Population status and distribution pattern of Assamese monkey. Total of 47 Assamese macaques were counted in four different troops. The group density was found to be 0.038 groups $/ \mathrm{km}^{2}$ with a population density of 0.44 individuals $/ \mathrm{km}^{2}$ and a mean group size of 11.75 (range $3-16$ ) individuals. Age sex composition of macaque comprised $23.40 \%$ adult males, $19.14 \%$ adult females followedby $17.02 \%$ sub adult male, $19.14 \%$ young adult female, $14.8 \%$ juveniles and $6.38 \%$ infants. Adult sex ratio was observed 1:0.81 i.e. 122 males per 100 females and the recruitment rate was found 0.33 . i.e. 33 infants per 100 females. The distribution pattern of Assamese macaques among four different study blocks was found clumped distribution in the study area. There was significant difference in distribution of Assamese macaques among four different blocks $\left(x^{2}=6.2996\right.$, d.f. $=3, p$ $=0.09791, p>0.05)$.
\end{abstract}

Keywords: Assamese monkeys, block design,census, direct observation

\section{INTRODUCTION}

Assamese monkeys has been categorized as endangered species by International Union for Conservation of Nature (IUCN) Red list category and one of the protected species by National Parks and Wildlife Conservation Act 1973 due to the low population and conservation threats (Janawali et al., 2011). They are kept as Appendix II of Convention on International Trade inEndangered Species (CITES) (Chalise, 2013a).Assamese monkeys inhabit in the mountains and hills along the Himalayas. This species has been reported from Nepal, India (Medhi et al., 2007), Bhutan (Kawamoto et al., 2006) Myanmar, Bangladesh (Menon, 2003; Chalise, 2011) Thailand, and southernmost China and Laos (Zhou et al., 2011; Timmins \& Duckworth, 2013). It is recorded from North Thailand ranging $610 \mathrm{~m}$ to $1830 \mathrm{~m}$ asl (Sanjaya et al., 2003). Chalise (2013a) recorded it from $380 \mathrm{~m}$ in Mulghat, Tamor to $2350 \mathrm{~m}$ asl Langtang, Nepal. It is reported to cover wider geographical ranges, rather fragmented population, distributed along rivers in the tropical and subtropical areas. The reported areas covered Kankai valley of Ilam, Sabhaya Valley and its range further extended west to Makalu Barun National Park, Melamchi, 
Langtang National Park, Nagarjun Area of Shivapuri Nagarjun National Park, Makwanpur, Dhading, Myagdi, Ramdi, Palpa and Achham district (Chalise, 2003, 2008; Wada, 2005) to Chamelia river basin (N 2948'34.6" E08051'02.8', 1607m) of Api Nampa Conservation Area (Chalise, 2013a).

The Assamese monkeys of Nepal is designated as "Nepal Population" by the South Asian Primate Conservation Assessment and Management Plan Workshop in 2002 due to morphological variation from the existing two subspecies i.e. Macaca assamensis assamensis and Macaca assamensis pelops, based on their fur coloration, head body-tail length and its ratio size variation and weight (Molur et al,. 2003). The 'Nepal Population' consists of overall darker fur color with fleshy pink face and the nasal area is darker than so far described population of this species (Chalise, 2005). So the Assamese macaque of Nepal may be a new subspecies of Assamese monkey but needs further molecular genetic analysis to confirm taxonomic status (Chalise, 2003). Furthermore a distinct difference in color also has been found in macaques recorded in higher and lower elevations of the country; facial color is different in male and females; males are fleshy-yellow-white and females are pink-blood coloured. Pelage is tanned blackish-ashy to blonde-hairs in both sexes (Chalise et al., 2005).

The population is recorded in Nepal during first decade of 2000 from different sites shows altogether 282 mature individuals while total population with different age and sex comprises up to 525 (Chalise, 2004a, 2004b; Chalise, 2005). Assamese census was conducted in different occasion revealed that 1099 individual in 51 troops are recorded from East Makalu to West Api area of Nepal (Chalise, 2013a)" This paper highlights the population status and spatial distribution of Assamese monkeys in Kaligandaki River Basin of Baglung and Parbat districts Nepal.

\section{MATERIALS AND METHODS}

\section{Study area}

Baglung and Parbat districts of Dhawalagiri Zone are two of the seventy-five districts of Nepal, lies in the mid-western development region of the country. The district Baglung is a part of Province No. 6, with its district headquarters Baglung, cover an area of $1,784 \mathrm{~km}^{2}$ and have a population (2001) of 268,938 . It extends from $28^{\circ} 15^{\prime} \mathrm{N}$ to $28^{\circ} 37^{\prime} \mathrm{N}$ latitude and $83^{\circ} 14^{\prime \prime} \mathrm{E}$ to $83^{\circ} 36^{\prime \prime} \mathrm{E}$ longitude andelevation ranges between $560 \mathrm{~m}$ to $1650 \mathrm{~m}$. Parbat district is a hilly area of Nepal. The district Parbat is a part of Province no 4 and one of the seventy-five district of Nepal. The district, with Kusma as its district headquarters, covers an area of $494 \mathrm{~km}^{2}$ and has a population (2001) of 157,826 . It extends from $28^{\circ} 00^{\prime} 19^{\prime \prime} \mathrm{N}$ to $28^{\circ} 23^{\prime} 59^{\prime \prime} \mathrm{N}$ latitude and $83^{\circ} 33^{\prime} 40^{\prime \prime} \mathrm{E}$ to $83^{\circ} 49^{\prime} 30^{\prime \prime}$ E longitude (Paudel, 2016). 


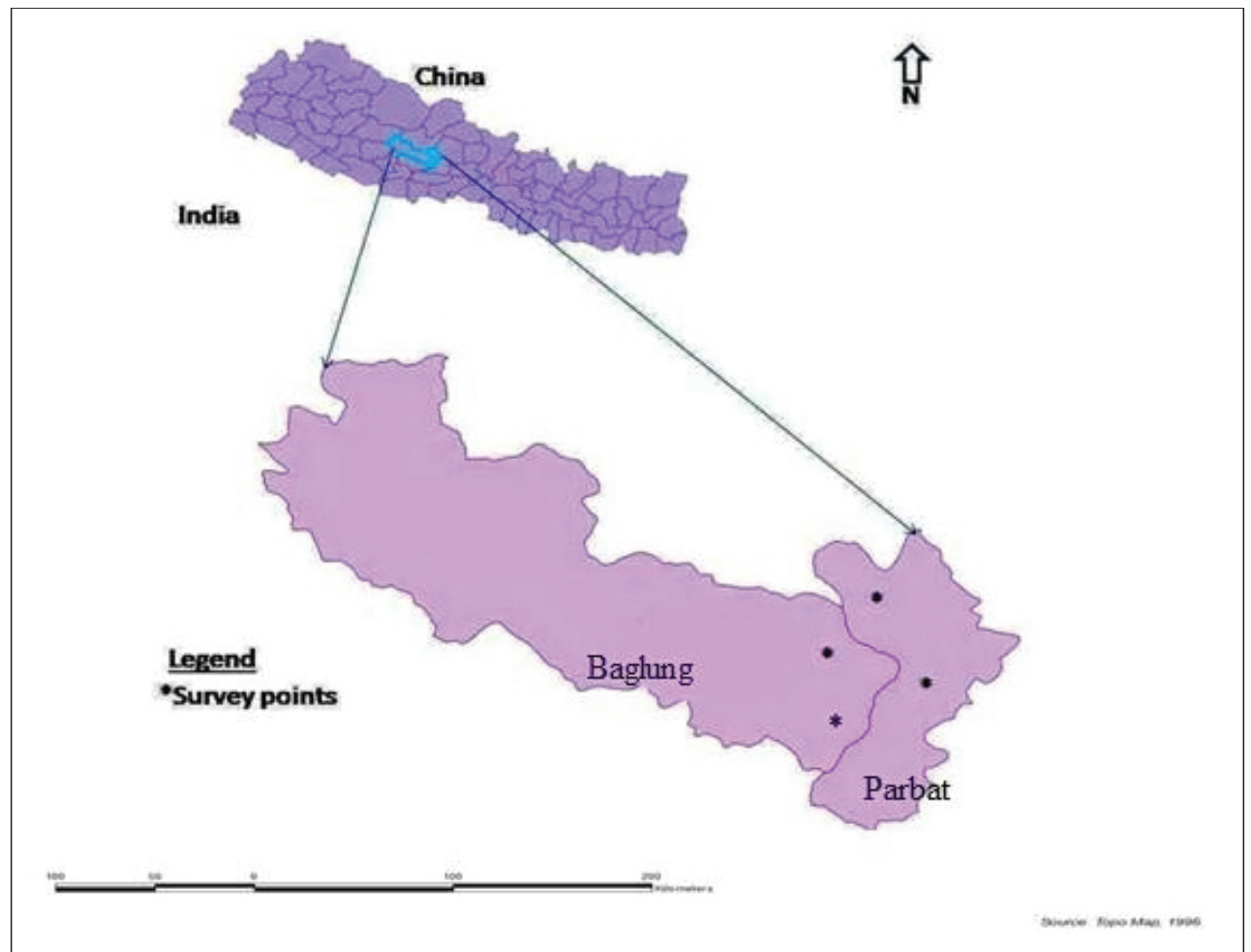

FIG. 1. Study area with survey grids in Kaligandaki River basin of Baglung and Parbat districts, Nepal.

Total area of Baglung site VDCs is $71.3452 \mathrm{~km}^{2}$ whether Parbat site VDCs is $33.357 \mathrm{~km}$ 2. The study area lies in between tropical to temperate belt of Nepal. This study area has a unique geographical feature having both North and South facing topography. The rain-bearing wind from the Bay of Bengal blows from the east towards west of Nepal during the rainy season. The climate of study area and its vicinity is mainly dry and wet (NG/RDHM, 2015). The average maximum temperature was recorded $\left(27.70^{\circ} \mathrm{C}\right)$ and minimum temperature was recorded $\left(15.30{ }^{\circ} \mathrm{C}\right)(\mathrm{NG} / \mathrm{RDHM}, 2015)$. According to the climatic data, average monthly relative humidity (at morning) of the area $77.17 \%$ and average monthly relative humidity (at evening) of the area $78.15 \%$. The highest precipitation was recorded $(553.6 \mathrm{~mm})$ in the month of July during the study period, while there were not recorded of precipitation in the month of November and December (NG/RDHM, 2015). The study area is rich in biodiversity. The reason for this may be due to presence of alluvial soil along the basin of this large Kaligandaki River, and high productivity of tropical deciduous riverine forest (Chalise, 2013b). Though in broad classification the study area falls in Shorea-Diospyros zone (Paudel, 2016). Mixed type of forest (Shorea, Diospyros and Schima) is found in the study area. Tropical deciduous riverine forest sub-tropical grassland and sub-tropical evergreen forest are the forest types in the study area (Chalise, 2013b). 
A preliminary field survey was donefrom November 9, 2015 to November 15, 2015" to understand the geophysical, climatic condition as well as to understand the population status and distribution of Assamese monkey. To study the Assamese monkey, the study area was divide into Four blocks namely Block A (Chisti, Jaidi, Arjewa and Binamare VDCs), Block B (Kusmisera, Amalachaur and NarayansthanVDCs), Block C (Siwalaya \& Pang, VDC) and Block D (Nangliwang and Dhairing VDCs). Blocks are designed on the basis of habitat character which were separated by large Kaligandaki river i.e. Block $A$ and $B$ from Baglung district site where as Block $C$ and $D$ from Parbat district site. Population surveys throughout the study area $\left(104.70 \mathrm{~km}^{2}\right)$ were carried out from all the possible trails; the trails were walked slowly at $0.5 \mathrm{~km} / \mathrm{hr}$., covering the $6 \mathrm{~km} /$ day. Species was identified through field guide books (Shrestha, 2003; Jnawali et al., 2011) and ages, sex of the macaques were distinguished by the published guidelines (Chalise, 1997; Ross \& Reeve, 2003).Observers will be placed along trails stopping every 100 meters to search the area for $1 / 2$ hour by applying both visual and auditory cues simultaneously as described in (Altman, 1974).

\section{RESULTS AND DISCUSSION}

\section{Population status of Assamese macaque}

In the study site a total of 47 individuals of Assamese macaques (Macaca assamensis) (fig. 1) were counted in four different troops during the field study dated on "9 November, 2015 " to "28 June, 2016". The minimum of Assamese macaques were reported from the Balewa Troop of Amalachaur VDC whereas maximum numbers of Assamese Macaques were reported in Aduwabari Troop of Chisti VDC.

TABLE 1.Troop of Assamese macaques in different block in the Kaliganaki river basin Baglung and Parbat districts Nepal at 2016.

\begin{tabular}{|c|c|c|c|c|}
\hline Block & Co-ordinates & Altitude (m) & No. of troop & Troop size \\
\hline A (Aduwabari) & $\begin{array}{l}\text { N 28005'05.02" } \\
\text { E 83035'18.59" }\end{array}$ & 687 & 1 & 16 \\
\hline B (Balewa) & $\begin{array}{l}\text { N 28011'47.5" } \\
\text { E 83039'083" }\end{array}$ & 750 & 1 & 3 \\
\hline C (Pang) & $\begin{array}{l}\text { N 28014'45.8" } \\
\text { S 83038'30" }\end{array}$ & 925 & 1 & 15 \\
\hline D (Dhairing) & 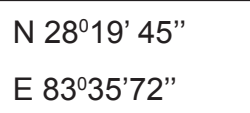 & 1096 & 1 & 13 \\
\hline Total & & & 4 & 47 \\
\hline
\end{tabular}




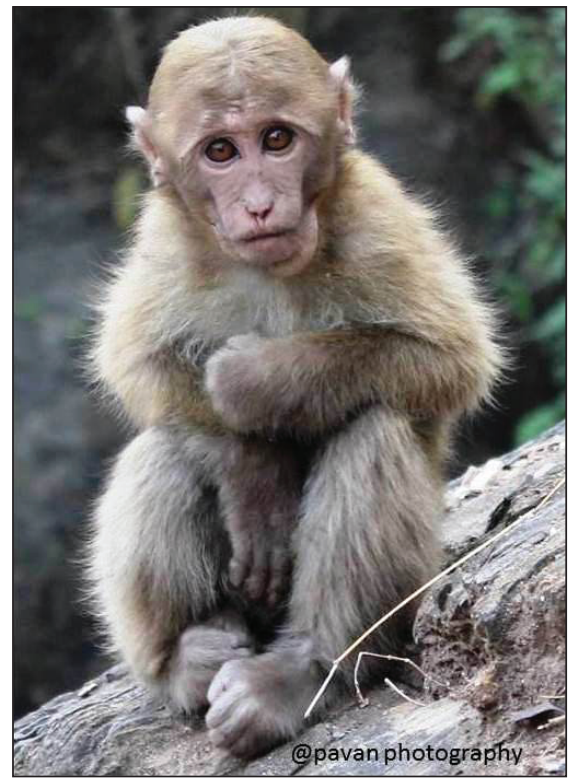

FIG.1 A. The Assamese macaque.

\section{Groups and population density}

Total of 47 Assamese macaques were observed which were existing in 4 groups in $104.70 \mathrm{~km}^{2}$ area. The mean group size was found 11.75 (Range 3-16) individuals. The group density was found 0.038 groups $/ \mathrm{km}^{2}$ with a population density of 0.44 individuals $/ \mathrm{km}^{2}$.

\section{Age-sex composition}

Age-sex composition of the Assamese troops recorded in the study area showed the highest percentage of adult male $11(23.40 \%)$ followed by adult female $9(19.14 \%)$ sub-adult male 8 $(17.02 \%)$, young - adult female $9(19.14 \%)$, juvenile $7(14.8 \%)$ and infant $3(6.38 \%)$.

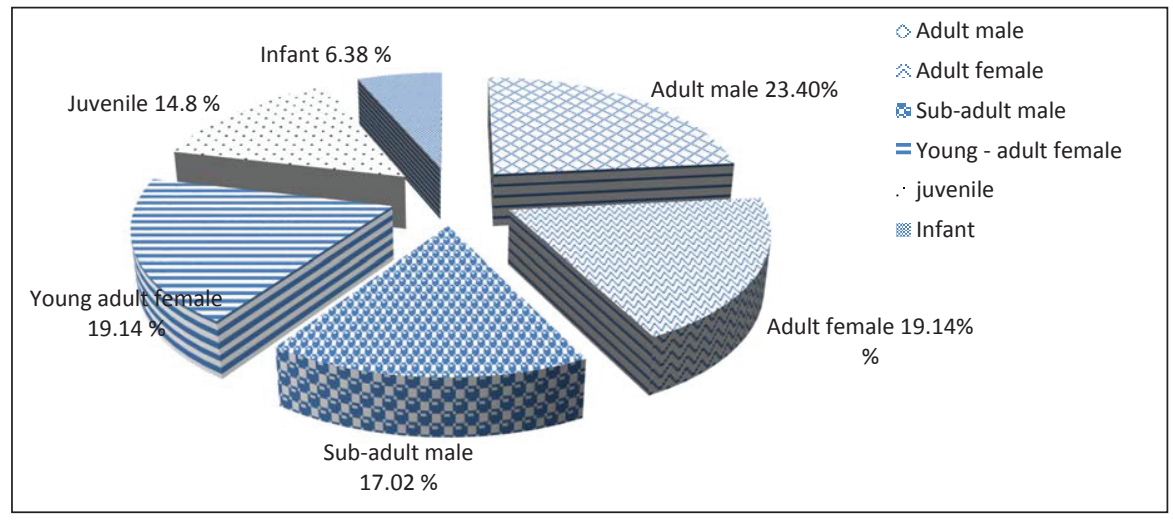

FIG. 2. Age-sex composition (\%) of Assamese monkeys in the Kaliganaki river basin Baglung and Parbat districts Nepal. 


\section{Adult sex ratio}

The adult sex ratio (male to female) observed during the entire study was 1.22 (122 male per 100 females) i.e. 1:0.81. The adult sex ratio was 1.33 (133 male per 100 females) i.e. 1:0.75 in block $A$ and in block C, 1 (100 male per 100 females) i.e. 1:1 in block B and in block D.

\section{Recruitment rate (Birth rate)}

Recruitment rate (female to infant ratio ) observed during the entire study area 0.33 (33 infant per 100 female). The recruitment rate was 0.33 (33 infants per 100 female) in block $A$ and in block C,0.5 (50 infants per 100 female) in block $D$ and 0 in block $B$.

\section{Distribution of Assamese macaques in different blocks}

Assamese macaques were recorded from all the four blocks of the study area. The study area Baglung and Parvat district river basin VDCs, was divided in to four different study blocks. One troop with 16 individuals were recorded in block $A$, where 4 adult males and 3 adult females with three sub adult male, 3 young adult female, 2 juveniles and 1 infant were found in Aduwabari of Chisti VDC Baglung having less human interference and plenty of food and water sources. In block B, one troop with 3 individuals were found in block B. Where 1 adult male, 1 adult female, with 1 juvenile were found near the Takuri at Amalachaur VDC Baglung having more human interferance and the habitat is fragmented by newly born Kaligandaki corridor. One troop with 15 individuals of assamese were observed in block $C$ where 4 adult male, 3 adult female, 2 sub-adult male, 3 young-adult female, 2 juvenile and 1 infant were found in Kushma municipality, 4, salghari pang parvat at the edgg of pang tari village with south facing rocky out crop. One troop with 13 individuals were recorded in block $D$. Where 2 adult male, 2 adult female , 3 sub-adult male, 3 young-adult female, 2 juvenile and 1 infant were found in Dhairing VDC parvat at the edge of salyan village.

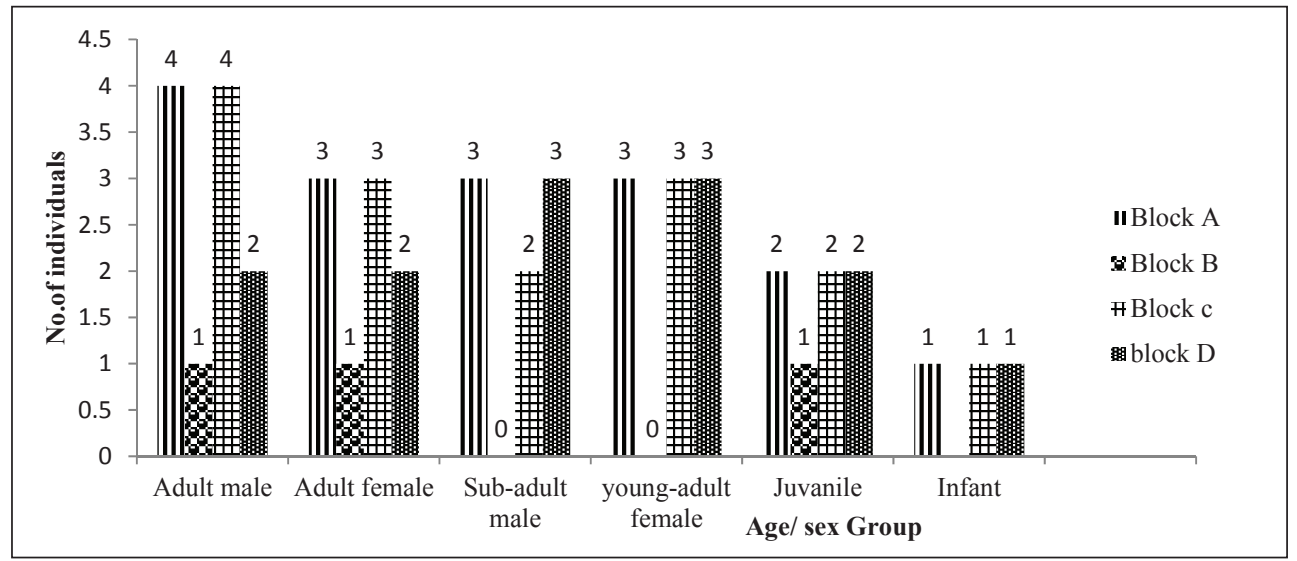

FIG. 3. Distribution of Assamese macaques in different blocks in the Kaliganaki river basin Baglung and Parbat districts Nepal.

The variance to mean ratio was used to determine the distribution pattern of Assamese Macaques among four different study blocks. The calculated value of varience to mean ratio was found to be 1.51. Since, the value of $\left(S^{2} / X\right) \square 1$, The result has shown clumped distribution 
of Assamese macaque in study area. Chi-square significance test showed that there was significant difference in distribution of Assamese macaques Among four different blocks. $\left(X^{2}\right.$ $=6.2996$, d.f. $=3, p=0.09791, p>0.05$ ).

During this study Assamese macaques in Baglung and Parbat, Kaligandaki river basin VDCs were found distributed in four different blocks. A total of 47 individuals in 4 different troops (16, 3, 15 and 13) were recordedfrom Aduwari, Balewa, Pang and Dhairing respectively however, Adhikari (2013) also recorded the similar result where three troops of Assamese Macaques having total 53 individuals from three different blocks in which 13, 15 and 25 in number from Paune, Jagat and Chipla respectively, may be due to presence of similar type of habitat in between these study site similar type of result were obtained during this study compared to Adhikari (2013). Chalise et al. (2013) had recorded the similar result where three troops of Assamese macaque having total 83 individuals in Nagarjun forest of SNNP; troop size recorded was 35 from Fulbari, 32 from Simpani area and 17 from Sanagaun-Mudkhu. Chalise (2000) reported seven troops of Assamese macaques in Makalu-Barun area in 1997 and estimated group size of 7-50 and the ratio of adult males to the adult females were 1:2.03 and again, in 1998 from the same study area, he reported 1:1.9 adult sex- ratios from group size in range of 13-27 of 4 troops. Southwick et al.(1964) reported two troops of Assamese monkeys in Darjeeling and estimated group size of $10-25$ and the ratio of adult male to the adult female were 1:1.7 Regmi (2008) recorded 9 Assamese macaques troops in LNP and observed troop size ranges from 13-23 individuals and the ratio of adult males to the adult females were 1:1.92. Adhikari (2013) reported three troops of Assamese macaques in Lamjung and estimated group size 13-25 and the ratio of adult males to the adult female were 1:2.14. Whereas, the present study recorded 4 Assamese macaques troops and observed troop size varies from 3-16 individuals in Baglung and Parbat, Kaligandaki River Basin VDCs. The adult sex ratio of Assamese macaques troop observed in this study i.e. 1:0.81 is a apparently not similar to that of the above stated in the study of Chalise (2000a) i.e. 1:2.03 in 1997, 1:19 in 1998, Regmi (2008) i.e. 1:1.7 and Adhikari (2013) i.e. 1:1.92 i.e. Macaque live in multi - male, Female - kin bonded groups and the ratio of male to females ranges from 1:2.2 Macaca radiate to 1:9 Macaca nemestriana (Feeroz, 1996). This finding do not supports that the Macaca assamensis also live in multi-male and female-kin, bonded groups like as other macaques.

Hanya et al. (2003) estimated the group density of Japanese macaques as 1.43 and 0.737 group $/ \mathrm{km}^{2}$ in disturbed and undisturbed area by the method of combining point census and group fallow within a census area of $7 \mathrm{~km}^{2}$ in the western area of Yakusima, an island in South Japan. Regmi (2008) reported the group density of Assamese macaques as 0.0790 groups/ $\mathrm{Km}^{2}$ in LNP where as in the present study the group density of Assamese macaques was found to be 0.016 group $/ \mathrm{km}^{2}$ by applying a total population count within a census of $183 \mathrm{Km}^{2}$. Moreover, Hanya et al. (2003) in the same study area, population was calculated to be 22.9 and 11.8 individuals $/ \mathrm{km}^{2}$ in the distributed and undistributed area respectively with the main group size of 16. Regmi (2008) also estimated the population density of Assamese macaque was found to be 1.8691 individuals $/ \mathrm{km}^{2}$ with the mean group size of 23.66 and Adhikari (2013) reported the population density of Assamese macaques 0.28 individuals $/ \mathrm{km}^{2}$ with the mean group size of 17.66 in Lamjung whereas in the present study, the population density of 
Assamese macaque was found to be 0.44 individuals $/ \mathrm{km}^{2}$ with mean group size 11.75 the reason behind this difference in density is due to comparatively large area of present study and the population also from outside of the protected area where there is no any rules and regulation effectively implemented by the government to protect this fragmented population from being vanish. Ale (2010) estimated the population density of Highland langurs in LNP using line transect method covering the area of $32 \mathrm{~km}^{2}$ was found to be 4.65 langurs $/ \mathrm{km}^{2}$. Wangchuk (1995) calculated the population density of Golden langurs using the same method covering the area of $58.5 \mathrm{~km}^{2}$ was found to be 2.1 langurs $/ \mathrm{km}^{2}$, but I observed population study of Assamese macaque in my study site was found to be 0.44 individuals $/ \mathrm{km}^{2}$. Severel study shows that environmental constrains and human interference might affect group composition and group size of the macaques (Machairas et al., 2003). Actually, this study area bears high human population as well as very high crop food and newly constructed Kaligandaki corridor road way due to which the Assamese macaques are distributed in very limited space of the study area where as small group size three observed in block B (Amalachaur troop). Due to presence of high human pressure and less resource of food the group size may affect itself when such effect is probably found by the patchiness of resource distribution. The variance to mean ratio of Assamese macaques from different study blocks was found to be more than one. The result showed clump distribution which is the most common type of distribution and also called as cluster or contagious and aggregated. It may be due to the response of seasonal weather, environmental changes and social behavior as well as it may tend to concentrate around a geographical feature that provides nutrients or shelter and when the occurrence of small sized groups (including blanks) and large sized groups is more frequent and the occurrence of middle sized group less frequent then expected in those studied blocks. This finding supports the idea of (Smith, 1996; Odum, 1996).

Total population of Assamese macaque was recorded to be 47 from four troops in Kligandaki river basin, Baglung and Parvat Districts during the study period of " 9 November, 2015" to "28 June, 2016". Maximum number was reported from block A (Aduwabari Troop) and minimum number was recorded in block B (Balewa Troop). Distribution of Assamese macaques in four blocks of study area was found to be clumped type of distribution. The sex ratio of Assamese macaques was found to be 1:0.81 i.e. 122 males per 100 females. There were more males then females, which did not depart significantly from 1:1 sex ratio. Average group size was found 11.74 individual in the study area.

\section{ACKNOWLEDGEMENTS}

The authors acknowledge National Trust for Nature Conservation for providing research grant. Gratefulness is expressed to the people of large Kaligandaki river basin VDCs for support that unexplored population to explore. The authors are also grateful to Shivish Bhandari for his kind help. Gratitude is expressed to the Central Department of Zoology and Department of Forest, Babarmahal Kathmandu, Nepal for allowing this study.3.

\section{REFERENCES}

ADHIKARI, R K (2013) Population status, distribution and general behavior of Assamese Macaque (Macaca assamensis, McClelland, 1840) in Taghring and Ghermu VDCs, Lamjung, Nepal. M.Sc Thesis, 
Central Department of Zoology, Tribhuvan University, Kirtipur, Kathmandu, Nepal.

ALE, P B (2010) Population, habitat and behavioral study of high land langur Semnopithecus entellus in Langtang National Park, Nepal. M.Sc. Thesis, Central Deppartment of Zoology, Tribhuban University, Kirtipur, Kathmandu, Nepal.

ALTMAN, J (1974) Observation of study of behavior: sampling methods. Behavior 49: 227-265.

CHALISE, M K; KARKI, J B; GHIMIRE, M K (2005) Status in Nepal: non-human primate. Specialissue of $10^{\text {th }}$ Wildlife Week, DNPWC, Nepal;pp 19-26.

CHALISE, M K (1997) Survey of primate in Makalu-Barun Conservation Area (Lower parts of Apsuwa, Isuwa and Sankhuwa River). A research report submitted to MBCA Project,Nepal.

CHALISE, M K (2000) Behavior study of Assamese monkey (Macaca assamensis) of Makalu Barun Area, Nepal. Proceeding of Third National Conference on Science and Technology, Kathmandu, Nepal; pp 1323-1332.

CHALISE, M K (2003) Assamese Macaques (Macaca assamensis) in Nepal. Primate Conservation 19: 99-107.

CHALISE, M K (2004a) A case of population stability of semi-provisioned, free-ranging temple Rhesus monkeys of Kathmandu valley, Nepal. Proceedings of the Fourth National Conference on Science and Technology, Kathmandu, Nepal; pp 324-325.

CHALISE, M K (2004b) Nepalka Banyajantu, Bhag 3 (Nepal's Wildlife, Part 3). Natural History Society of Nepal, Kathmandu, Nepal; 74+6 p (in Nepali).

CHALISE, M K (2005) New characters of Assamese monkeys in Nepal. (Abs) National Conference on Animal Taxonomy - Emerging Trends Department of Zoology, Sacred Heart College, Thevara, ochi682013 Kerela, India; pp 14-15.

CHALISE, M K (2008) Primate census in Kathmandu and west parts of Nepal. Journal of Natural History Museum23:60-64.

CHALISE, M K (2011) Notes on Hanuman langurs and Assamese monkeys of Central Zoo, Nepal.Central Zoo Newsletter Quarterly Publication 39:3-4.

CHALISE, M K (2013a) Fragmented primate population of Nepal. In MARSH, L K; CHAPMAN,C A (eds) Primates in fragments: complexity and resilience, developments in primatology: progress and prospects. Springer Science+Business Media; New York, USA; pp. 329-356.

CHALISE, M K (2013b) Biodiversity conservation and sustainable management of living natural resources Kaligandaki Upper hydropower project, Nepal. A report submitted to Nepalconsult, HES and NESS (P.) Ltd, Nepal.

CHALISE, M K; BHATTARAI, G P; PANDEY, B(2013) Ecology and behavior of Assamese monkey in Shivapuri Nagarjung National Park. Nepal. Journal of Natural History Museum 27:12-24.

FEEROZ, M M (1996) Behavioral ecology and conservation of pig tailed Macaque (Macaca nemestrina leniona) in Bangladesh. University of Cambridge,Cambridge, UK.

HANYA, G; YOSHIHIRO, S; ZAMMA, K; KUBO, R; TAKAHATA, Y (2003) New method to census primates groups:eEstimating group density of Japanese Macaques by point census. Am J Primatol60:43-56.

JNAWALI, S R; BARAL, H S; LEE, S; ACHARYA, K P; UPADHYAY, G P; PANDEY, M; SHRESTHA, R; JOSHI, D; LAMICHHANE, B R; GRIFFITHS, J; KHATIWADA, A; AMIN,R (compilers) (2011). The status of Nepal mammals: The National Red List Series. Department of National Parks and Wildlife Conservation, 
Kathmandu, Nepal.

KAWAMOTO, Y; AIMI, M; WANGCHUK, T; SHERUB (2006) Distribution of Assamese macaques (Macaca assamensis) in the inner Himalayan region of Bhutan and their mtDNA diversity. Primates 47(4):388-392.

MACHAIRAS, I; CAMPERIO, A C; SGARDELIS, S (2003) Interpopulation differences in activity patterns of Macaca sylvanus in the Moroccan Middle Atlas. Human Evolution18: 185-202.

MEDHI, R D; CHETRY, D;CHOUDHURY, D; BHATTACHARJEE, P C (2007) Status and diversity of temple primates in northeast India.Primate Conservation 22:135-138.

MENON, V (2003)A field guide to Indian mammals I: Dorling Kindersley (India) Pvt. Limited.

MOLUR, S; BRANDON-JONES, D; DITTUS, W; EUDEY, A; KUMAR, A; SINGH, M; FEEROZ, M M; CHALISE, M K; PRIYA, P; WALKER, S (2003) Status of south Asian primates: conservation assessment and anagement plan (CAMP) workshop report, viii+432,2002 March 5-9;Coimbatore, Tamil Nadu,India.

ODUM, E P (1996) Fundamental of ecology Dehradun, India: Natraj Publishers (3rd ed).

PAUDEL, P K (2016) Population status, distribution and general behavior of Assamese monkey (Macaca assamensis McClelland, 1840) in Kaligandaki River Basin, Baglung and Parbat Districts, Nepal. M.Sc. Thesis, Central Department of Zoology, Tribhuban University, Kirtipur, Kathmandu Nepal.

REGMI, G R (2008) Status of Assamese macaque (Macaque assamensis, McCland 1840) in Langtang National Park.M.Sc. Thesis, Central Department of Zoology, Tribhuban University, Kathmandu, Nepal.

ROSS, C; REEVE, N (2003) Survey and census methods: population distribution and density. In SETCHELL,J M; CURTIS, D J (eds) Field and laboratory methods in primatology. Cambridge University Press; Cambridge, UK; pp 90-109.

SANJAY, M; DOUGLAS, B-J; WOLFGANG, D; ARDITH, E; AJITH, K; MEW. A S; FEEROZ, M M; CHALISE, M K; PADMA, P; SALLY, W (2003) Status of south Asian primates. Conservation assessment and management plan workshop report, Zoo Outreach Organization/CBSG-south Asia, Coimbatore, India.

SHRESTHA, T K (2003) Wildlife of Nepal.SHRESTHA, B; Kathamandu, Nepal.

SMITH, R L (1996) Ecology and field biology. Wesley Educational Publishe; USA (5th edition).

TIMMINS, R J; DUCKWORTH, J W (2013) Distribution and habitat of Assamese Macaque (Macaca assamensis) in Lao PRD, Including its use of Low-altitude Karsts. Primate Conservation 26:103-114.

WADA, K (2005) The distribution pattern of Rhesus and Assamese monkeys in Nepal. Primates 46:115119.

WANGCHUK, T (1995) A census and the bibliography of Golden langur (Presbytis geei) in Bhutan. Tiger Paper 22(3):1-6.

ZHOU, Q H ; WEI, Z ; HUANG, C (2011) Diet of the Assamese Macaque Macaca assamensis in limestone habitats of Noggin, China. Current Zoology 57(1):18-25. 